\title{
ОБРАЗНЫЕ СРАВНЕНИЯ И МЕТАФОРЫ - РЕПРЕЗЕНТАНТЫ ИНДИВИДУАЛЬНО-АВТОРСКОЙ КАРТИНЫ МИРА В ХУДОЖЕСТВЕННОМ ДИСКУРСЕ (НА ПРИМЕРЕ ПРОИЗВЕДЕНИЯ НЭНСИ МИТФОРД 'VOLTAIRE IN LOVE”')
}

\begin{abstract}
SIMILES AND METAPHORS - REPRESENTATIVES OF THE INDIVIDUAL AUTHOR'S PICTURE OF THE WORLD IN ARTISTIC DISCOURSE (ON THE EXAMPLE OF NANCY MITFORD'S WORK "VOLTAIRE IN LOVE")

E. Kuchinskaya

E. Cheremisova
\end{abstract}

Summary: Stylistic means (similes and metaphors) are considered in the novel "Voltare in Love" by Nancy Mitford. The figurative mechanism of the individual author's worldview is examined: the main conceptual features and concepts as well as models reflecting the author's worldview are revealed. The basis for comparison are identified for the first time.

Keywords: artistic discourse, simile, metaphor, Nancy Mitford, individual author's picture of the world.
Кучинская Елизавета Александровна

Д.филол.н., дочент, Военная академия войсковой противовоздушной обороны Вооруженных Сил Российской Федерации имени Маршала Советского Союза А.М. Василевского kuchinskaya@list.ru

Черемисова Елена Анатольевна Преподаватель, Военный Университет МО РФ 7313150@gmail.com

Аннотация: Рассматриваются стилистические средства (образные сравнения и метафоры) в романе Нэнси Митфорд “Voltaire in Love". Исследуется образный механизм функционирования индивидуально-авторской картины мира: выявляются основные понятийные признаки и концепты, а также модели, отражающие авторское мировидение. Впервые определяются основания для сравнений.

Ключевые слова: художественный дискурс, образное сравнение, метафора, Нэнси Митфорд, индивидуально-авторская картина мира.

Интерес ученых направлен на исследование «индивидуально-авторской картины мира», «концептосферы», «идиостиля» (В.С. Андреев, Е.С. Кубрякова, В.И. Карасик, 3.Д. Попова, И.А. Стернин, В.Е. Чернявская и др.).

И.А. Стернин и З.Д. Попова рассматривали картину мира как «упорядоченную совокупность знаний о действительности, сформировавшуюся в общественном (а также групповом, индивидуальном) сознании [9].

Образ мира - «это отображение в психике человека предметного мира, опосредованное предметными значениями и соответствующими когнитивными схемами и поддающееся сознательной рефлексии» [6, с. 268]. На основе данного заключения, мы можем сказать, что анализ художественной действительности писателя связан с восприятием авторского мира через призму личного опыта, отображенного в сознании.

Понимание текста связано с процессом перевода смысла этого текста в любую другую форму его закрепления; процессом смысловой компрессии; процессом построения образа предмета или ситуации, наделенного определенным смыслом. За текстом стоит изменяющийся мир событий, ситуаций, идей, чувств, ценностей человека - реальный мир [Там же: с. 141-142]. Попыта- 
емся раскрыть тот опыт и ценности, которые вложила в содержание текста английская писательница Нэнси Митфорд для понимания и формирования образа автора и познания ее авторского мира.

Индивидуальная картина мира писателя отражает его личное видение изображаемой реальности [7, с.139].

Выявление и анализ специфики функционирования стилистических средств (образных сравнений и метафор) в художественном дискурсе позволяет раскрыть индивидуально-авторскую картину мира Нэнси Митфорд, что обусловливает актуальность данного исследования.

Практическим материалом для анализа послужил роман "Voltaire in Love" (1957) английской писательницы Нэнси Митфорд, который принадлежит к историческому периоду творчества писательницы. Само творчество Вольтера и его жизнь воплощают характерные черты эпохи Просвещения, ее проблемы и сам человеческий тип просветителя: философа, писателя, общественного деятеля [3, с. 165].

Художественный дискурс - это носитель «культурной» печати конкретного этапа в истории общества [8, с.4].

В данном исследовании решаются следующие задачи:

1. выявить стилистические средства (образные сравнения и метафоры) в художественном произведении Н. Митфорд "Voltaire in Love" ;

2. выделить концепты, представленные моделями;

3. определить когнитивные признаки, на которых строится образное сравнение и метафора.

При проведении анализа стилистических средств, выявленных в романе Н. Митфорд, мы будем выделять концепт-цель (то, что сравнивается) жирным шрифтом, а концепт-источник (то, с чем сравнивается) пунктиром. Основания сравнений подчеркиваются.

Наши наблюдения над образными сравнениями позволили установить, что Нэнси Митфорд уделяет внимание поведенческим реакциям героев. Концепт «взгляд" представлен в следующем примере:

French aristocracy drew together, staring sadly but inertly at the fray like a herd of cows (p. 21).

Концептами-целями являются French aristocracy, staring, концептом-источником - herd of cows. Мы выделяем модель «общество-животные». По своему поведению, аристократическое общество сравнивается со стадом коров по признаку безучастности.
Следующий пример свидетельствует об интересе писательницы к окружающей действительности. В примере представлен концепт «пространство».

In the month of May 1726, Voltaire sailed up the Thames. It was one of those perfect days of early summer which make our island seem like fairyland (p.22).

Образное сравнение содержит концепт-цель - perfect days, концепт-источник - fairyland. Выделяется модель «время-сказка». Погода, которая стояла в Англии в день приезда Вольтера, сравнивается с волшебной сказкой по признаку красивого пейзажа.

В нижеприведенных примерах создается яркий образ героев путем их сравнения с выдающимися деятелями, а также описывается их эмоциональное состояние. Выделяется концепт «личность».

You think like Trajan, you write like Pling (p. 65).

Концепты-цели - think, write, концепты-источники Trajan, Pliny. Выделяется модель «действие-деятель». По своим способностям герой сравнивается с философом Траяном и писателем Плинием по признаку эрудиции.

В образном сравнении концептом-целью является eyes, концептом-источником - dead cinders. Выделяется модель «часть тела-пепел». Глаза герцога Сан-Симона были потухшими как пепел по признаку тягостного эмоционального состояния.

The Duke Saint-Simon's eyes were like dead cinders. The Duke never came to supper for fear of being obliged to return hospitality (p. 6).

Мы отмечаем заинтересованность писательницы к предметам обихода. Концепт «работа» репрезентирован в примере:

He thought that an historical study should be composed like a play, with a beginning, a middle and an end (p. 52).

В образном сравнении содержатся концепты-цели historical study, be composed, концепт-источник - play. Выделяется модель «труд-пьеса». Историческое исследование должно быть похоже на пьесу по признаку содержания.

Также Нэнси Митфорд уделяет внимание теме провидения. Концепт «судьба» представлен в следующем примере:

The love of Voltaire and the Marquise du Chatelet was not an ordinary love. They were not ordinary people. Voltaire's Memoires begin with their meeting which he regarded as the turning point of his life (p. 1).

1 Здесь и далее примеры из романа Н. Митфорд "Voltaire in Love" приводятся по изданию [11] с указанием страниц в круглых скобках 
Концептом-целью служит meeting, концептом-источником - turning point. Выделяется модель «встречарешающий момент». Вольтер считал встречу с маркизой дю Шатле переломным моментом своей жизни. Признаком образного сравнения является предначертанность судьбы.

Наблюдается интерес писательницы к эстетике. Выделяется концепт «красота»

His appearance was delightful, a droll, impertinent, inquisitive look, dancing black eyes, a turned-up nose, elegant little figure, beautifully dressed, he was like a creature of spun glasss (p. 11).

В образном сравнении концептом-целью является he, концептом-источником - creature of spun glass. Выделяется модель «человек-материал». Внешность Вольтера отличалась от внешности других молодых людей и привлекала к себе внимание по признаку импозантности.

Переходя к анализу метафоры, необходимо отметить, что в нашем исследовании мы рассматривали концептуальные метафоры, которые являются «феноменами мышления и культуры, структура которых, содержит когнитивную структуру «источника» (source domain) и когнитивную структуру «цели» (target domain)» [5, с. 9].

А теперь приведем примеры метафор, анализ которых, позволил прийти к выводу, что писательница уделяет внимание окружающему миру, красоте и сверхъестественным способностям. Здесь был выделен концепт «здание» Рассмотрим следующие примеры:

His Court was a toy model_of Versailles (p. 181).
Метафора содержит концепт-цель - Court, концептисточник - a toy model of Versailles. Выделяется модель «двор-игрушка». Двор сравнивается с игрушечной моделью Версаля по имплицитному признаку размера.

The great territorial nobles, now powerless but decorative, had two professions open to them: the Court and the Army. Magical Versailles was their reward for this loss of power ( $p .3$ ).

Концепт-цель - magical Versailles, концепт-источник reward. Мы выделяем модель «двор-подарок». Версаль сравнивается с вознаграждением по имплицитному признаку свободы, которую он представлял собой для высшего общества.

Концепт «личность» представлен в нижеприведенных примерах:

The Marquise was a jewel. She was beautiful, clever and an excellent hostess (p. 185).

Концепт-цель - Marquise, концепт-источник - jewel. Выделяется следующая модель - «человек-украшение». Маркиза сравнивается с драгоценностью по имплицитному признаку ценности, которую она представляет собой.

She was a fairy who had lived in a perpetual masquerade (p.171).

В метафоре концептом-целью выступает she, концептом-источником - fairy. Выделяется модель «человекволшебное существо». Героиня сравнивается с феей по имплицитному признаку сверхъестественных способностей.

Результаты проведенного анализа представлены в

Специфика индивидуально-авторской картины мира Нэнси Митфорд

\begin{tabular}{|c|c|c|}
\hline Концепт & Модель & Когнитивный признак \\
\hline \multicolumn{3}{|c|}{ Образные сравнения } \\
\hline Взгляд & общество-животные & безучастность \\
\hline пространство & время-сказка & красивый пейзаж \\
\hline личность & действие-деятель & эрудиция \\
\hline личность & часть тела-пепел & тягостное эмоциональное состояние \\
\hline работа & труд-пьеса & содержание \\
\hline судьба & встреча-решающий момент & предначертанность судьбы \\
\hline внешность & человек-материал & импозантность \\
\hline \multicolumn{3}{|c|}{ Метафоры } \\
\hline Концепт & Модель & Когнитивный признак \\
\hline здание & двор-игрушка & размер \\
\hline здание & двор-подарок & свобода \\
\hline личность & человек-украшение & ценность \\
\hline личность & человек-волшебное существо & сверхъестественные способности \\
\hline
\end{tabular}


нижеприведенной таблице:

Таким образом, наше исследование позволило сделать следующие выводы:

- Образные сравнения и метафоры являются лингвокогнитивной основой индивидуальноавторской картины мира, и являются главными эмоционально-экспрессивными средствами художественного дискурса Нэнси Митфорд.

- Писательница Нэнси Митфорд использует широкий спектр образных сравнений, с помощью которых достигается эмоциональная насыщенность и раскрываются субъективно-оценочные отношения в ее произведении и повышается выразительный потенциал художественного текста. В ходе анализа было выявлено 60 образных сравнений и 25 метафор.
- B романе "Voltaire in Love" были установлены концепты, обобщающие знания писательницы о мире и человеке и свидетельствующие в целом об интересе писательницы к антропоцентризму. Концепты-цели и концепты-источники представлены в основном лексикой с положительной окраской.

- Впервые были выявлены когнитивные признаки для образных сравнений и метафор, которые помогают глубже раскрыть индивидуально-авторский механизм функционирования образных сравнений и метафор.

- Данный анализ показал, что центром индивидуально-авторской картины мира писательницы является концепт «личность».

- Результаты данного анализа послужат основой для дальнейшего исследования творчества Нэнси Митфорд.

\section{ЛИТЕРАТУРА}

1. Арутюнова Н.Д. Дискурс. Лингвистический энциклопедический словарь [Электронный ресурс]. - Режим доступа:http://lingvisticheskiyslovar.ru/ description/diskurs/168 (дата обращения: 19.04.2021).

2. Виноградов В.В. 0 теории художественной речи [Электронный ресурс]. - Режим доступа: https://drive.google.com/file/d/0Bz0oqt94KN0xTeTBXMWpzUnc/ view (дата обращения: 19.04.2021).

3. История зарубежной литературы XVIII века: учебник / Д.Г. Алилова, Е.М. Апенко, А.В. Белобратов и др. - 4-е изд., перераб. - СПб.: Изд-во С.-Петерб. ун-та, 2019.С. 165.

4. Карасик В.И. О категориях дискурса [Электронный ресурс].URL:http://homepages.tversu.ru/ ips/JubKaras.html (дата 0бращения: 19.04.2021).

5. Лакофф Джордж, Джонсон Марк Метафоры, которыми мы живем. - Изд. 3-е. - М.: Издательство ЛКИ, 2017. С. 9.

6. Леонтьев А.А. Основы психолингвистики. - 3-е изд. - М.: Смысл; Спб.: Лань, 2003. - С. 141-142; 268.

7. Лугаськова И.П. Индивидуальная картина мира автора как отображение художественной картины мира эпохи [Электронный ресурс]. - Режим доступа: https://cyberleninka.ru/article/n/individualnaya-kartina-mira-avtora-kak-otobrazhenie-hudozhestvennoy-kartiny-mira-epohi/viewer (дата обращения: 19.04.2021).

8. Норец М.В. Художественный дискурс: филологический анализ текста: монография. - Севастополь: РИБЕСТ, 2016. С. 4.

9. Стернин И.А., Попова 3.Д. Текст-дискурс-картина мира [Электронный ресурc].URL:https://www.vsu.ru/ru/university/structure/communicate/pdf/text-disc/ text-disc1.pdf (дата обращения: 19.04.2021).

10. Чернявская В.Е. Лингвистика текста. Лингвистика дискурса: учеб. пособие. - 5-е изд., стер. - М.: ФЛИНТА: Наука, 2018.

11. Mitford N. Voltaire in Love. Vintage books, 2011.

( К Кучинская Елизавета Александровна (kuchinskaya@list.ru), Черемисова Елена Анатольевна (7313150@gmail.com). Журнал «Современная наука: актуальные проблемы теории и практики» 